\title{
STUDI KONSEP RENCANA DAN STRATEGI PROGRAM BIKE TO SCHOOL DI KOTA BANDUNG
}

\author{
Ina Helena \\ Program Studi Perencanaan Wilayah dan Kota, Fakultas Teknik, \\ Universitas Islam Bandung \\ Jl. Tamansari No. 1 Bandung, 40116
}

\begin{abstract}
ABSTRAK
Transportasi adalah kegiatan perpindahan orang atau barang dari satu tempat (asal) ke tempat lain (tujuan) dengan menggunakan sarana kendaraan bermotor maupun tidak bermotor. Transportasi terbagi menjadi beberapa jenis yaitu transportasi darat (mobil, motor, kereta api, sepeda, dll), udara (pesawat terbang, helikopter, dll), dan laut (perahu layar, perahu dayung, kapal motor, dll).

Metode analisis yang digunakan dalam penelitian ini adalah Analitycal Hierarchy Process. Analitycal Hierarchy Process adalah salah satu metode yang digunakan dalam menyelesaikan masalah yang mengandung banyak kriteria. AHP bekerja dengan cara memberi prioritas kepada alternatif yang penting mengikuti kriteria yang telah ditetapkan. Lebih tepatnya, AHP memecah berbagai peringkat struktur hirarki berdasarkan tujuan, kriteria, sub- kriteria, dan pilihan atau alternative.

Dari hasil analisis, ada beberapa variabel untuk mendukung strategi dan program Bike To School, seperti : ketersediaan sepeda, Perizinan dari orang tua untuk memperbolehkan anaknya menggunakan sepeda, Penyediaan parkir sepeda di sekolah, Penyediaan jalur sepeda, Melakukan kampanye penggunaan sepeda, Ketersediaan marka dan rambu-rambu sepeda dan Memberikan pendidikan mengenai keselamatan berkendara sepeda.
\end{abstract}

Keyword : Bike To School, Bandung, AHP.

\section{Pendahuluan}

Transportasi adalah kegiatan perpindahan orang atau barang dari satu tempat (asal) ke tempat lain (tujuan) dengan menggunakan sarana kendaraan bermotor maupun tidak bermotor. Transportasi terbagi menjadi beberapa jenis yaitu transportasi darat (mobil, motor, kereta api, sepeda, dll), udara (pesawat terbang, helikopter, dll), dan laut (perahu layar, perahu dayung, kapal motor, dll). Transportasi darat merupakan jenis alat transportasi yang paling banyak digunakan oleh masyarakat karena biaya perjalanan yang jauh lebih murah dan mudah untuk digunakan baik oleh pribadi maupun umum
Salah satu contoh perpindahan atau perjalanan yang dilakukan adalah perjalanan siswa menuju ke sekolah. Perjalanan ini umumnya dilakukan dari hari Senin hingga Jumat dengan waktu pergi dan pulang yang relatif sama. Dengan banyaknya jumlah penduduk usia sekolah seperti jumlah murid SD di Kota Bandung berjumlah 231.549 orang dengan jumlah sekolah mencapai 989 SD, sedangkan jumlah siswa SMP sebesar 101.556 orang dengan jumlah sekolah mencapai 214 SMP. Sementara itu, ada 83.073 siswa SMK dengan jumlah sekolah mencapai 132 SMK dan 48.640 siswa SMA dengan jumlah sekolah mencapai 135 SMA, sehingga menjadikan banyaknya sekolah di Kota Bandung. Sehingga diperlukan adanya moda transportasi 
yang menunjang kebutuhan perjalanan menuju sekolah yang memadai. Salah satu program Pemerintah Kota Bandung dalam bidang transportasi adalah program Bike To School dimana arti dari Bike To School ini adalah komunitas pelajar yang menggunakan sepeda sebagai alat transportasi dari rumah ke sekolah dan sebaliknya.

Hal ini menjadi potensi terlebih untuk siswa sekolah untuk mulai menggunakan sepeda ke sekolah karena penggunaannya yang ramah lingkungan dan sudah dianggap mampu untuk menjaga keselamatan dan keamanan ketika menggunakan sepeda oleh orang tua mereka. Sehingga penggunaan sepeda menjadi salah satu alternatif yang dapat digunakan para siswa untuk sampai ke sekolah. Sepeda dapat digunakan dengan kecepatan rata-rata 20 $\mathrm{km} / \mathrm{jam}$ dan daya jelajah sekitar 1-5 kilometer.

Adapun manfaat yang didapatkan dengan menggunakan sepeda yakni dilihat dari segi kesehatan akan melatih pernafasan untuk bernafas lebih panjang agar organ-organ dalam tubuh dapat bekerja secara optimal selain itu dengan bersepeda dapat menurunkan berat badan, hanya dengan 15 menit bersepeda 5 - 6 kali dalam seminggu, dapat mengurangi berat badan sekitar 11 pon dalam satu tahun. Sementara dilihat dari segi lingkungan, menurut berbagai penelitian semakin menguatkan manfaat menggunakan sepeda terhadap kelestarian lingkungan, jarak 4 mil menggunakan sepeda akan menghindarkan sekitar 15 pon polutan memenuhi udara yang dihirup bersama.

\section{Maksud, Tujuan dan Sasaran}

Adapun maksud, tujuan dan sasaran dari Usulan Konsep Rencana \& Strategi Program Bike To School Kota Bandung, yaitu:

a. Maksud

Maksud dari Usulan Konsep Rencana \& Strategi Program Bike To School Kota Bandung adalah untuk merancang program bike to school yang sesuai dan terencana agar tercapai tujuan yakni seluruh siswa di Kota Bandung menggunakan sepeda ke sekolah sebagai salah satu cara untuk menurunkan tingkat polusi, meningkatkan kesehatan bagi para siswa, dan mewujudkan Kota Bandung sebagai Kota Sepeda.

b. Tujuan

Sementara tujuan dari kegiatan ini adalah menyusun rancangan program bike to school di Kota Bandung yang sesuai dan terencana agar tercapai tujuan yakni seluruh siswa di Kota Bandung menggunakan sepeda ke sekolah sebagai salah satu cara untuk menurunkan tingkat polusi, meningkatkan kesehatan bagi para siswa, dan mewujudkan Kota Bandung sebagai Kota Sepeda.

c. Sasaran

Adapun sasaran dari kegiatan ini yaitu:

- Mendapatkan gambaran eksisting dari program bike to school saat ini

Menyusun visi, misi, strategi dan program yang perlu dilakukan agar program bike to school berhasil diwujudkan.

Ruang lingkup wilayah dari kegiatan ini adalah seluruh sekolah di Kota Bandung. Untuk lebih jelasnya dapat dilihat pada

\section{Gambar 1. Peta Sebaran Sekolah di Kota} Bandung

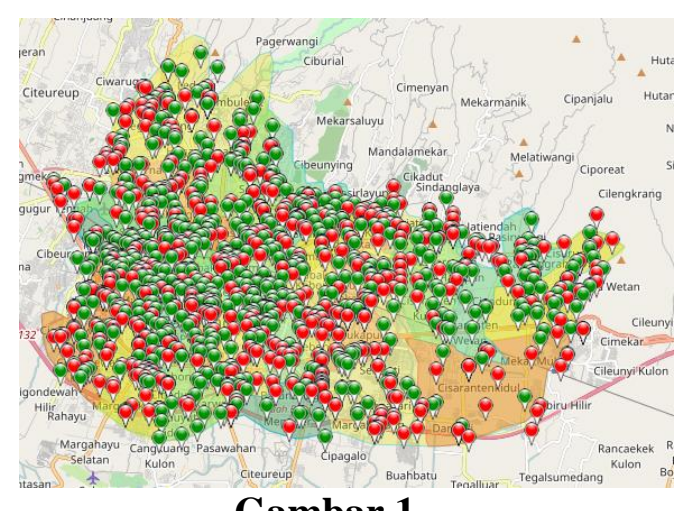

Gambar 1

Peta Sebaran Sekolah di Kota Bandung

Sumber: disdik.jabarprov.go.id/

Keterangan: , $\theta$ Negeri $\vartheta$ Swasta

\section{Studi Literatur}

Rencana penataan jaringan jalur sepeda di Kota Bandung sudah pernah dilakukan pada tahun 2010 dan 2014. Pada tahun 2010, adalah rencana awal jalur sepeda meliputi kawasan Jl. Ir. H. Juanda (Simpang Dago sampai persimpangan Jl. Sulanjana), Jl. Diponegoro 
(dari depan Gedung Sate sampai dengan persimpangan dengan Jalan Sulanjana), sebagian Jl. Aceh, J1. Merdeka, dan J1. Banda

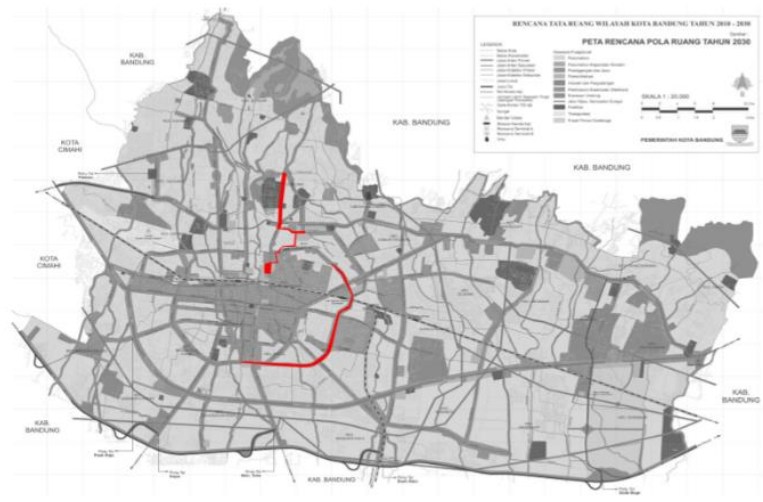

Gambar 2

Rencana Jalur Sepeda

Sumber: Masterplan Jalur Sepeda

Pada Tahun 2014 rencana penataan jalur sepeda merupakan rencana lanjutan dari yang sudah pernah direncanakan sebelumnya pada tahun 2010, Pada tahun ini, rencana penataan jalur sepeda difokuskan untuk pengembangan alternatif jalur sepeda melalui kawasan perumahan/permukiman penduduk untuk menghubungkan pusat-pusat aktivitas pengguna sepeda seperti pusat pendidikan, perkantoran, dan kantor-kantor pemerintah

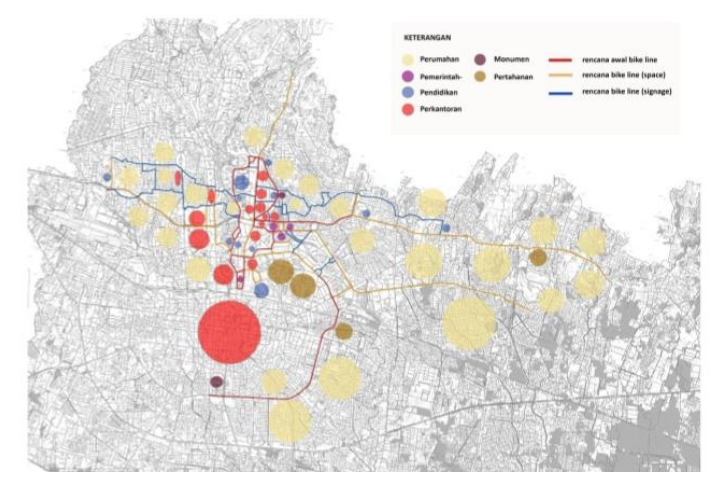

Gambar 3

Peta Rencana Jalur Sepeda

Sumber: Masterplan Jalur Sepeda

Berdasarkan kriteria pemilihan jalur dan tipe jalur sepeda yang dijelaskan pada bab 3 dan hierarki serta ROW jalan di Kota Bandung, berikut adalah tipikal jalur sepeda yang diusulkan:

1. Jalur Tipe A, dimana jalur sepeda terpisah dari jalur kendaraan bermotor dan terletak di badan trotoar, sejajar dengan jalur pejalan kaki.

2. Jalur Tipe B, pada tipe iini jalur sepeda berada di badan jalan sejajar dengan jalur kendaraan bermotor, namun dipisahkan secara tegas oleh separator pembatas.

3. Jalur Tipe C, pada tipe ini jalur sepeda berada di badan jalan sejajar dengan jalur kendaraan bermotor dan dipisahkan oleh garis marka jalan.

4. Jalur Tipe D, pada tipe ini jalur sepeda berada di badan jalan sejajar dengan jalur kendaraan bermotor, Pada tipe $\mathrm{C}$ ini jalur sepeda bersatu dengan jalur kendaraan bermotor dan pada lajur yang merupakan jalur untuk sepeda diberikan lambang sepeda. Tipe ini berlaku jika ROW jalan sangat sempit dan tidak memungkinkan untuk meletakkan jalur sepeda yang terpisah.

5. Jalur Tipe E, tipe jalur ini terdapat pada jalan-jalan kecil yang merupakan jalan alternatif bagi sepeda dan terletak di jalan lingkungan atau jalan perumahan. Pada tipe ini jalur sepeda bercampur dengan jalur kendaraan bermotor dan ditandai dengan adanya signage.

\section{Metodologi}

Dalam kegiatannya pelajar akan melakukan perjalanannya menuju rumah ke sekolah, dan sebaliknya. Maka akan terbagi atas 3 (tiga) jenis data yang dibutuhkan yaitu data dari rumah, data dari perjalanan dan data dari sekolah. Data dari rumah berupa kepemilikan sepeda, kepemilikan lahan parkir untuk sepeda, perizinan dari orangtua dan kendala kepemilikan sepeda yang data tersebut didapatkan dengan cara menyebarkan kuesioner. Untuk data perjalanan, yang dibutuhkan adalah ketersediaan jalur sepeda, ketersediaan marka dan rambu khusus sepeda, jarak maksimal penggunaan sepeda dan hambatan selama perjalanan dengan cara mendapatkan data tersebut berupa survey instansional ke Dinas Perhubungan Kota Bandung, Dinas Pekerjaan Umum Kota Bandung, selain itu juga cara mendapatkan data tersebut menggunakan kuesioner, internet dan Masterplan Jalur Khusus Sepeda Kota 
Bandung. Sedangkan, data dari sekolah adalah lahan parkir khusus sepeda di sekolah, regulasi sekolah terkait, jumlah siswa keseluruhan dan cakupan pembagian wilayah rayon yang didapatkan dengan cara survey instansional ke Dinas Perhubungan Kota Bandung, Dinas Pekerjaan Umum Kota Bandung dan Dinas Pendidikan serta internet

Metode analisis yang digunakan adalah metode analisis statistik deskriptif untuk mengetahui persentase alat transportasi yang digunakan oleh para siswa dan fakto-faktor pendukung lainnya yakni dengan Analisis Hirarki Proses (AHP) yang digunakan untuk mengambil keputusan menurut para ahli terkait strategi program untuk mewujudkan bike to school.

Adapun rancangan program yang diusulkan adalah program sumbangan sepeda dari pihak negeri maupun swasta, kampanye penggunaan sepeda yang aman dan selamat, kebijakan yang diperlukan dari Pemerintah Kota Bandung, Dinas Perhubungan, Dinas Pendidikan dan sekolah terkait, pembangunan parkir khusus sepeda di sekolah, pendidikan mengenai penggunaan sepeda yang berkeselamatan, penyediaan rambu dan marka sepeda, pembatasan parkir kendaraan bermotor, penjaminan keselamatan bagi siswa yang menggunakan sepeda. Untuk lebih jelasnya lihat Gambar 4. Kerangka Pikir Penelitian.

Metode analisis yang digunakan dalam penelitian ini adalah Analitycal Hierarchy Process. Analitycal Hierarchy Process adalah salah satu metode yang digunakan dalam menyelesaikan masalah yang mengandung banyak kriteria. AHP bekerja dengan cara memberi prioritas kepada alternatif yang penting mengikuti kriteria yang telah ditetapkan. Lebih tepatnya, AHP memecah berbagai peringkat struktur hirarki berdasarkan tujuan, kriteria, sub- kriteria, dan pilihan atau alternative

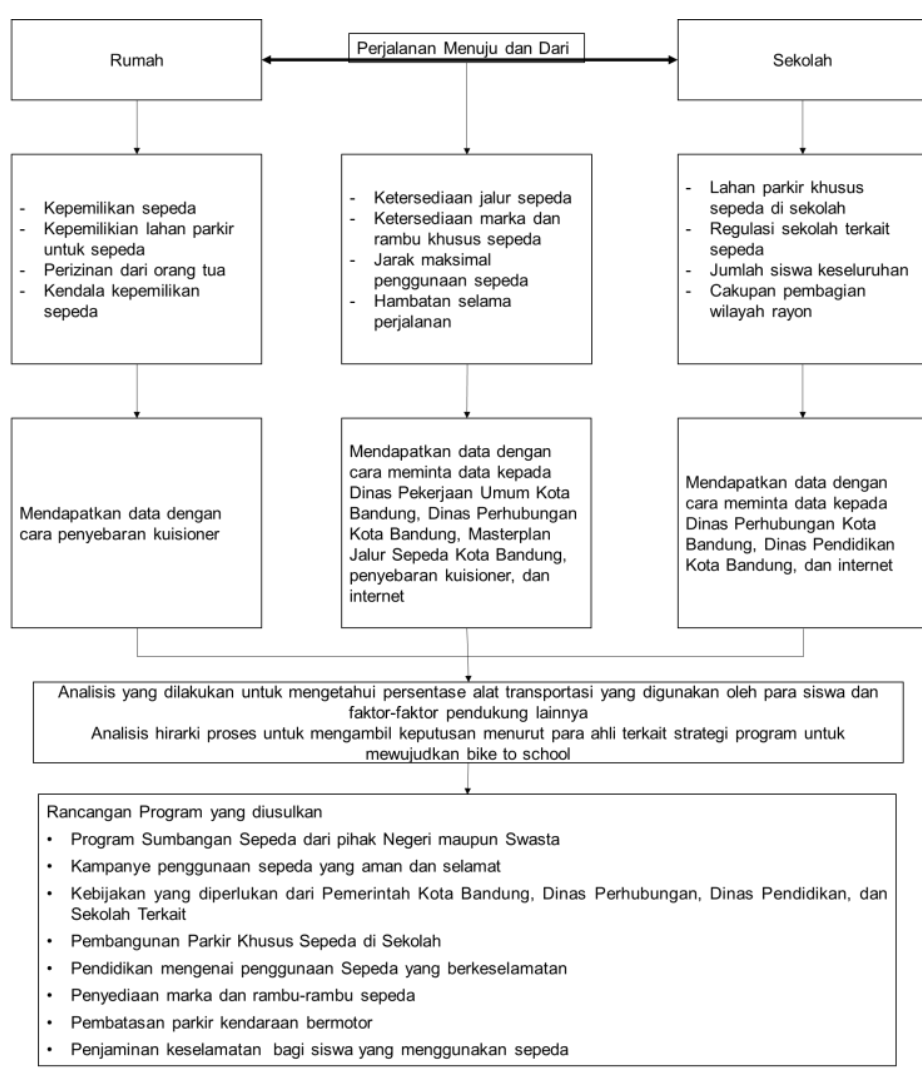

Gambar 4. Kerangka Pikir Penelitian.

Adapun kerangka penyelesaian yang telah disusun oleh peneliti, untuk lebih jelasnya lihat Gambar 5. Langkah Penyelesaian Penelitian

Adapun manfaat dari penggunaan Analytical Hierarchy Process, antara lain yaitu:

a. Memadukan intuisi pemikiran, perasaan dan penginderaan dalam menganalisis pengambilan keputusan

b. Memperhitungkan konsistensi dari penilaian yang telah dilakukan dalam membandingkan faktor-faktor yang ada,

c. Memudahkan pengukuran dalam elemen,

d. Memungkinkan perencanaan ke depan. 


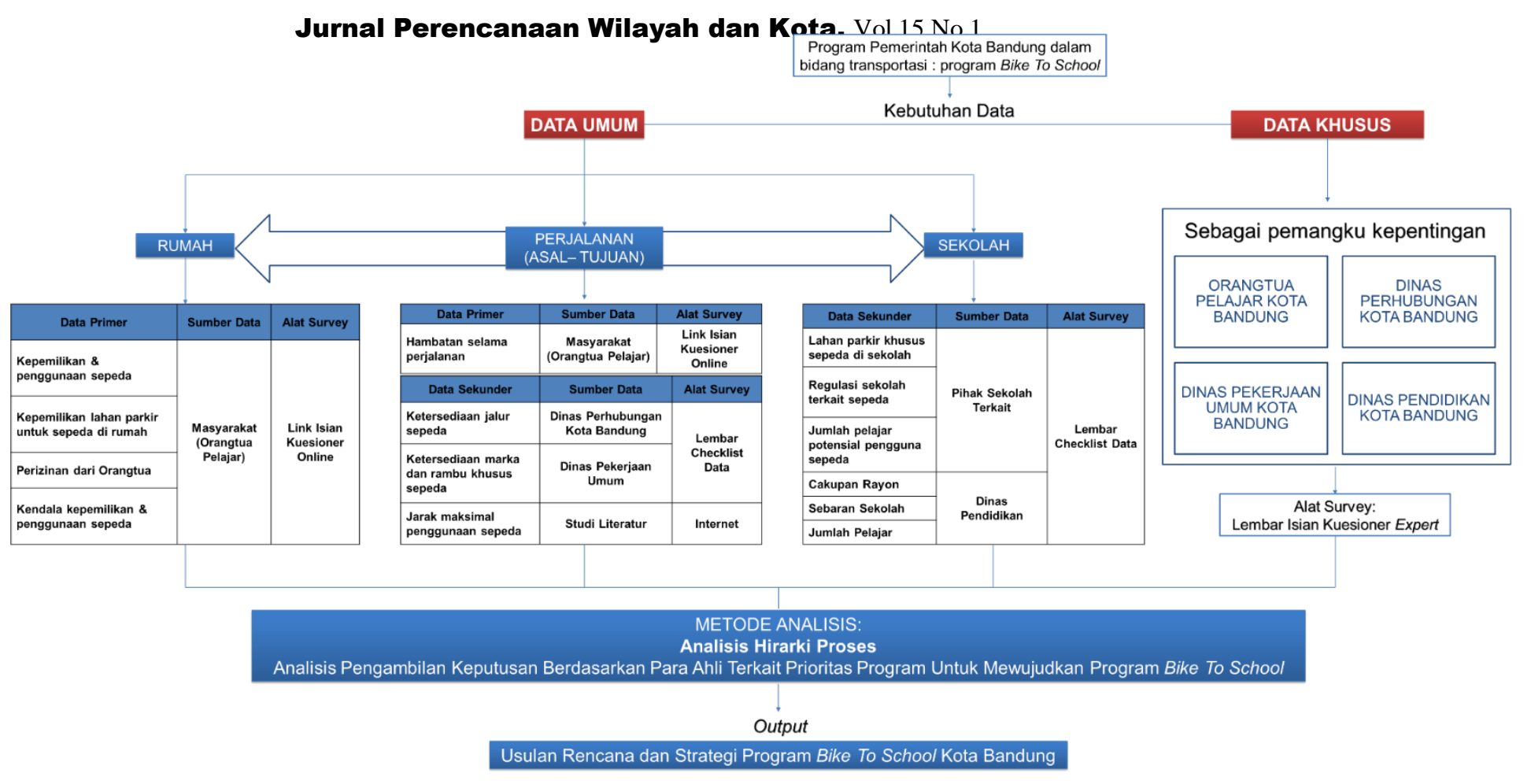

Gambar 5

Langkah Penyelesaian Penelitian

Secara umum pengambilan keputusan dengan metode AHP didasarkan pada langkahlangkah berikut:

1. Mendefinisikan masalah dan menentukan solusi yang diinginkan.

2. Membuat struktur hirarki yang diawali dengan tujuan umum, dilanjutkan dengan kriteria-kriteria dan alternaif-alternatif pilihan yang ingin di rangking.

3. Membentuk matriks perbandingan berpasangan yang menggambarkan kontribusi relatif atau pengaruh setiap elemen terhadap masing-masing tujuan atau kriteria yang setingkat diatasnya. Perbandingan dilakukan berdasarkan pilihan atau judgement dari pembuat keputusan dengan menilai tingkat tingkat kepentingan suatu elemen dibandingkan elemen lainnya.

4. Menormalkan data yaitu dengan membagi nilai dari setiap elemen di dalam matriks yang berpasangan dengan nilai total dari setiap kolom.

5. Menghitung nilai eigen vector dan menguji konsistensinya, jika tidak konsisten maka pengambilan data ( preferensi ) perlu diulangi. Nilai eigen vector yang dimaksud adalah nilai eigen vector maksimum yang diperoleh dengan menggunakan matlab maupun dengan manual.

6. Mengulangi langkah 3, 4, dan 5 untuk seluruh tingkat hirarki.

7. Menghitung eigen vector dari setiap matriks perbandingan berpasangan. Nilai eigen vector merupakan bobot setiap elemen. Langkah ini untuk mensintesis pilihan dalam penentuan prioritas elemenelemen pada tingkat hirarki terendah sampai pencapaian tujuan.

8. Menguji konsistensi hirarki. Jika tidak memenuhi dengan $\mathrm{CR}<0$, 100; maka penilaian harus diulang kembali.

\section{Hasil dan Analisis}

Berdasarkan teori sampling pada bab 3, bahwa jumlah sampling minimum adalah 30 . Sehingga peneliti mengambil jumlah sampling 
bagi orang tua sebanyak 30 responden. Dari hasil 30 kuesioner yang disebar secara online bagi orangtua pelajar, maka akan didapatkan hasil dari respondennnya, yaitu:

1. Kepemilikan dan penggunaan sepeda Dari hasil kuesioner terdapat jumlah total kepemilikan sepeda yakni 46 unit dari 30 responden, jika di rata-rata maka jumlah sepeda yang dimiliki responden adalah 2 unit. Sehingga jumlah total kepemilikan sepeda di Kota Bandung berdasarkan hasil kuesioner dapat dilihat pada perhitungan di bawah ini:

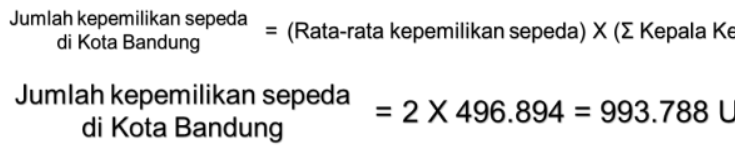

Dengan jumlah sepeda sebanyak 993.788 unit di Kota Bandung tidak akan mempengaruhi terhadap tingkat kemacetan Kota Bandung, hal ini disebabkan oleh jalan Kota Bandung yang memiliki Ruang Manfaat Jalan (RUMAJA) yang terbatas, namun dalam penggunaannya, sepeda ini dapat mereduksi tingkat polusi udara di Kota Bandung. Untuk lebih jelasnya lihat perhitungan dibawah ini:

- Beban jalan = (Jumlah sepeda) $\mathrm{X}$ (satuan mobil penumpang (smp) sepeda)

- Beban jalan $=993.788 \times 0,3$

- Beban jalan = 298.136 smp

Dapat disimpulkan dari asumsi diatas bahwa jika penggunaan 993.788 unit sepeda membebani jalan sebesar $298.136 \mathrm{smp}$.

2. Kepemilikan lahan parkir sepeda dirumah

Dari hasil kuesioner terhadap 30 responden, jika di persentase maka $100 \%$ responden tersebut memiliki lahan parkir untuk sepeda dirumah, hal ini dikarenakan sepeda hanya membutuhkan space/ruang penyimpanan yang kecil/sedikit.

3. Perizinan dari orangtua

Dari hasil kuesioner, jika di persentase maka $100 \%$ responden tersebut yang tidak lain adalah kepala keluarga, memberikan izin terhadap anaknya untuk mengendarai sepeda ke sekolah, dikarenakan jarak sekolah yang dekat dengan rumah.

4. Kendala kepemilikan dan penggunaan sepeda

Dari hasil kuesioner, terdapat kendala kepemilikan dan penggunaan sepeda yakni $70 \%$ responden tersebut menjawab kendala tersebut disebabkan harga sepeda yang mahal, dan $30 \%$ responden lainnya menjawab bahwa kendala tersebut disebabkan oleh pendapatan yang rendah.

5. Hambatan selama perjalanan

Dari hasil kuesioner, terdapat permasalahan/hambatan selama perjalanan ketika menggunakan sepeda yakni 100\% responden menjawab bahwa permasalahan/hambatan yang terjadi adalah kurangnya kesadaran pengguna jalan/kendaraan lainnya terhadap pengguna sepeda, sehingga hal ini akan membuat pengguna sepeda harus sangat berhati-hati saat menggunakan sepeda.

Dalam menentukan variabel perlu dilihat juga mengenai keputusan seorang siswa untuk bersedia menggunakan sepeda ke sekolah. Dengan membuat diagram alir maka dapat diketahui permasalahan atau faktor penghambat penggunaan sepeda ke sekolah yang dapat dilihat pada Gambar 5.1. Adapun beberapa variabel yang menjadi penting untuk dapat mewujudkan program Bike to School dilandasi berdasarkan permasalahan atau kekurangan yang menyebabkan program Bike to School saat ini tidak berjalan maksimal. Adapun permasalahan yang dihadapi dapat dilihat pada tabel berikut.

\section{Tabel 1}

Identifikasi Penentuan Variabel

\begin{tabular}{|l|lr|l|}
\hline No & \multicolumn{2}{|l|}{ Permasalahan } & \multicolumn{1}{|c|}{ Variabel } \\
\hline 1 & Hanya $1 \%$ jalur & Penyediaan jalur \\
& khusus sepeda & sepeda \\
& yang tersedia di & \\
& jalan-jalan Kota & \\
& Bandung dan jalur & \\
& khusus sepeda & \\
& tersebut belum & \\
\hline
\end{tabular}




\begin{tabular}{|c|c|c|}
\hline No & Permasalahan & Variabel \\
\hline & $\begin{array}{lr}\text { terintegrasi } & \text { antara } \\
\text { satu } & \text { tempat } \\
\text { dengan } & \text { tempat } \\
\text { lainnya. } & \text { Jalur } \\
\text { khusus } & \text { sepeda } \\
\text { hanya terdapat di } & \\
\text { Jalan Diponogoro } \\
\text { (dari taman lansia) } \\
-\quad \text { Jalan Aria } \\
\text { Jipang - Jalan } \\
\text { Surapati, Jalan } \\
\text { Tamblong - Jalan } \\
\text { Asia Afrika, Jalan } \\
\text { Surapati - Jalan } \\
\text { Dipati Ukur, Jalan } \\
\text { Tamansari - Jalan } \\
\text { Ganesa, Jalan } \\
\text { Belitung-Jalan } \\
\text { Ambon, Jalan } \\
\text { Diponogoro- Jalan } \\
\text { Pranatayuda }\end{array}$ & \\
\hline 2 & $\begin{array}{l}\text { Hanya } 56 \text { sekolah } \\
\text { dari } 1.470 \text { sekolah } \\
\text { atau hanya } 4 \% \\
\text { sekolah memiliki } \\
\text { tempat parkir } \\
\text { khusus sepeda }\end{array}$ & $\begin{array}{l}\text { Penyediaan parkir } \\
\text { sepeda di sekolah }\end{array}$ \\
\hline 3 & $\begin{array}{l}\text { Minimnya marka } \\
\text { dan rambu-rambu } \\
\text { khusus sepeda } \\
\text { yang tersedia di } \\
\text { jalan-jalan Kota } \\
\text { Bandung. Marka } \\
\text { dan rambu-rambu } \\
\text { sepeda hanya } \\
\text { terdapat di Jalan } \\
\text { Dipatiukur, Jalan } \\
\text { Diponogoro } \\
\text { (Samping Taman } \\
\text { Lansia), Jalan } \\
\text { Diponogoro } \\
\text { (Gedung sate) } \\
\text { Tidak adanya } \\
\text { marka dan rambu- } \\
\text { rambu sepeda } \\
\text { dengan jenis } \\
\text { peringatan, yaitu: } \\
\text { - Kelandaian } \\
\text { jalan }\end{array}$ & $\begin{array}{l}\text { Ketersediaan } \\
\text { marka dan } \\
\text { rambu-rambu } \\
\text { sepeda }\end{array}$ \\
\hline
\end{tabular}

\begin{tabular}{|c|c|c|}
\hline No & Permasalahan & Variabel \\
\hline & $\begin{array}{l}\text { - Jalan licin } \\
\text { - Tempat } \\
\text { berhenti khusus } \\
\text { sepeda }\end{array}$ & \\
\hline 4 & $\begin{array}{l}\text { Berdasarkan hasil } \\
\text { kuesioner yang } \\
\text { telah disebar pada } \\
30 \text { responden, } \\
\text { penghambat } \\
\text { kepemilikan } \\
\text { sepeda karena } \\
\text { harga sepeda yang } \\
\text { cenderung mahal. }\end{array}$ & $\begin{array}{l}\text { Ketersediaan } \\
\text { sepeda }\end{array}$ \\
\hline 5 & $\begin{array}{l}\text { Masih rendahnya } \\
\text { pengetahuan } \\
\text { masyarakat } \\
\text { mengenai } \\
\text { keselamatan } \\
\text { berkendara sepeda } \\
\text { yang dapat dilihat } \\
\text { sangat jarang } \\
\text { sekali pesepeda } \\
\text { yang pung } \\
\text { menggunakan } \\
\text { helm, pelindung } \\
\text { sikut dan lutut, } \\
\text { lampu sepeda } \\
\text { ketika malam hari, } \\
\text { serta pengetahuan } \\
\text { terkait perilaku } \\
\text { sesama pengguna } \\
\text { jalan }\end{array}$ & $\begin{array}{l}\text { Memberikan } \\
\text { pendidikan } \\
\text { mengenai } \\
\text { keselamatan } \\
\text { berkendara } \\
\text { sepeda }\end{array}$ \\
\hline 6 & $\begin{array}{ll}\text { Saat ini kampanye } \\
\text { penggunaan } \\
\text { sepeda yang } & \\
\text { dilakukan } & \\
\text { berfokus } & \\
\text { siswa } & \text { SMP } \\
\text { terutama } & \text { SMP } \\
\text { negeri } & \\
\end{array}$ & $\begin{array}{l}\text { Melakukan } \\
\text { kampanye } \\
\text { penggunaan } \\
\text { sepeda }\end{array}$ \\
\hline 7 & $\begin{array}{l}\text { Orang tua } \\
\text { cenderung } \\
\text { khawatir ketika } \\
\text { anaknya } \\
\text { menggunakan } \\
\text { sepeda ke sekolah }\end{array}$ & $\begin{array}{l}\text { Perizinan dari } \\
\text { orang tua untuk } \\
\text { memperbolehkan } \\
\text { anaknya } \\
\text { menggunakan } \\
\text { sepeda }\end{array}$ \\
\hline
\end{tabular}

Analisis hirarki proses ini bertujuan untuk menyusun strategi yang perlu dilakukan 
untuk mewujudkan program Bike To School di Kota Bandung. Adapun beberapa strategi program yang diusulkan yaitu:

1. Penyediaan jalur sepeda

2. Penyediaan parkir sepeda di sekolah

3. Ketersediaan marka dan rambu-rambu sepeda

4. Ketersediaan sepeda

5. Memberikan pendidikan mengenai keselamatan berkendara sepeda

6. Melakukan kampanye penggunaan sepeda

7. Perizinan dari orang tua untuk memperbolehkan anaknya menggunakan sepeda

Dari ketujuh strategi yang diusulkan, maka susunan yang telah dihasilkan dari analisis hirarki proses dengan jumlah responden sebanyak 4 orang (Perwakilan dari Dinas Perhubungan, Dinas Pekerjaan Umum, Dinas Pendidikan, dan Orang tua) didapatkan hasil sebagai berikut:

1. Ketersediaan sepeda

2. Perizinan dari orang tua untuk memperbolehkan anaknya menggunakan sepeda

3. Penyediaan parkir sepeda di sekolah

4. Penyediaan jalur sepeda

5. Melakukan kampanye penggunaan sepeda

6. Ketersediaan marka dan rambu-rambu sepeda

7. Memberikan pendidikan mengenai keselamatan berkendara sepeda

\section{Kesimpulan}

Adapun kesimpulan dari keseluruhan penelitian mengenai Usulan Konsep Rencana dan Strategi Program Bike To School ini merumuskan visi dan misi sebagai berikut:

\section{A. Visi}

Mendorong pelajar untuk menggunakan sepeda sebagai alat transportasi seharihari dari rumah ke sekolah dan sebaliknya

\section{B. Misi}

- Meningkatkan penggunaan sepeda sebagai transportasi harian

- Mendukung terciptanya kota ramah lingkungan dengan rendahnya tingkat kemacetan dan tingkat polusi
- Meningkatkan pembangunan infrastruktur pendukung bagi pelajar pengguna sepeda

- Mendukung program sumbangan sepeda bagi pelajar

- Meningkatkan kegiatan sosialisasi/kampanye sepeda bagi pelajar

- Mendukung kebijakan keamanan dan keselamatan bersepeda bagi pelajar pengguna sepeda

- Mendukung pembatasan parkir bagi pelajar yang menggunakan kendaraan bermotor pribadi

Sementara susunan strategi yang diusulkan dengan program yang dapat mendukung perwujudan strategi tersebut dapat dijelaskan dalam tabel berikut.

Tabel 2

Strategi dan Program Pendukung Bike to School Kota Bandung

\begin{tabular}{|c|c|c|}
\hline No & Strategi & $\begin{array}{c}\text { Program } \\
\text { Pendukung }\end{array}$ \\
\hline 1 & $\begin{array}{l}\text { Ketersediaan } \\
\text { sepeda }\end{array}$ & 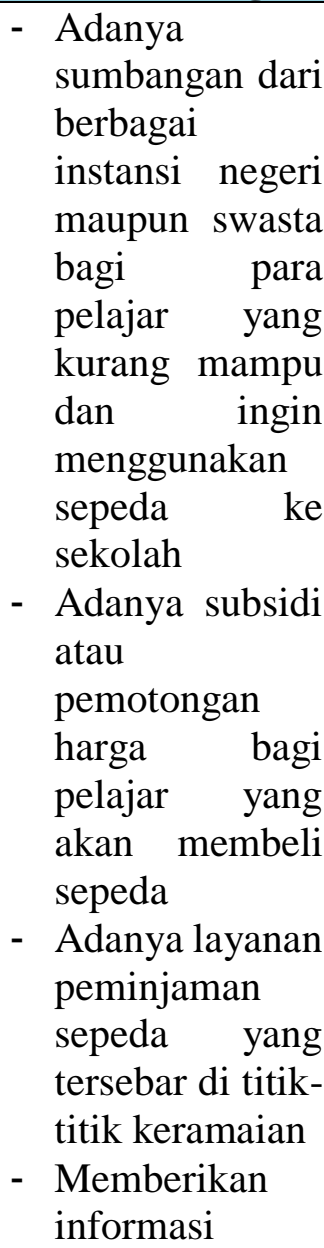 \\
\hline
\end{tabular}




\begin{tabular}{|c|c|c|}
\hline No & Strategi & $\begin{array}{c}\text { Program } \\
\text { Pendukung }\end{array}$ \\
\hline & & $\begin{array}{ll}\text { mengenai } & \text { jenis } \\
\text { sepeda yang } \\
\text { layak } \\
\text { digunakan } \\
\text { untuk kondisi } \\
\text { jalan di Kota } \\
\text { Bandung }\end{array}$ \\
\hline 2 & $\begin{array}{l}\text { Perizinan dari } \\
\text { orang tua untuk } \\
\text { memperbolehkan } \\
\text { anaknya } \\
\text { menggunakan } \\
\text { sepeda }\end{array}$ & $\begin{array}{l}\text { - } \text { Adanya } \\
\text { penjaminan } \\
\text { keselamatan } \\
\text { berupa asuransi } \\
\text { bagi para } \\
\text { pelajar yang } \\
\text { menggunakan } \\
\text { sepeda ke } \\
\text { sekolah } \\
\text { - Memberikan } \\
\text { informasi } \\
\text { mengenai } \\
\text { manfaat } \\
\text { bersepeda bagi } \\
\text { kesehatan dan } \\
\text { lingkungan }\end{array}$ \\
\hline 3 & $\begin{array}{l}\text { Penyediaan } \\
\text { parkir sepeda di } \\
\text { sekolah }\end{array}$ & 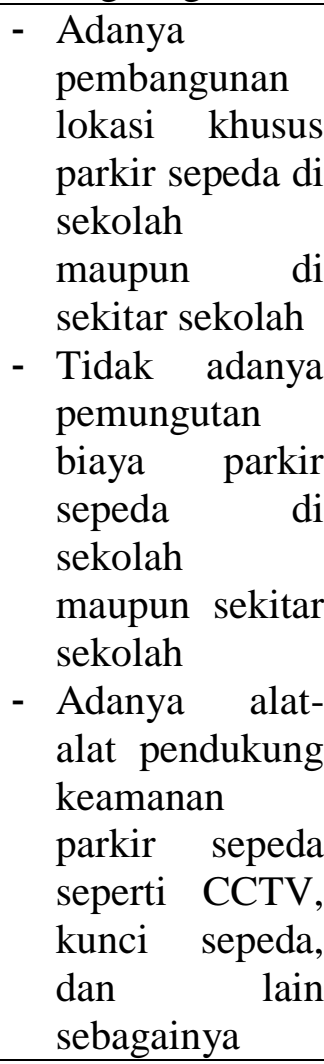 \\
\hline 4 & $\begin{array}{l}\text { Penyediaan jalur } \\
\text { sepeda }\end{array}$ & $\begin{array}{l}\text { Adanya } \\
\text { pembangunan } \\
\text { jalur } \quad \text { khusus }\end{array}$ \\
\hline
\end{tabular}

\begin{tabular}{|c|c|c|}
\hline No & Strategi & $\begin{array}{c}\text { Program } \\
\text { Pendukung }\end{array}$ \\
\hline & & $\begin{array}{l}\text { sepeda yang saling } \\
\text { berintegrasi dari } \\
\text { satu tempat ke } \\
\text { tempat lain }\end{array}$ \\
\hline 5 & $\begin{array}{l}\text { Melakukan } \\
\text { kampanye } \\
\text { penggunaan } \\
\text { sepeda }\end{array}$ & $\begin{array}{lr}\text { Adanya kegiatan } \\
\text { kampanye dari } \\
\text { pihak Dinas } \\
\text { Perhubungan } \\
\text { maupun dari pihak } \\
\text { Sekolah terkait } \\
\text { manfaat dari } \\
\text { penggunaan } \\
\text { sepeda }\end{array}$ \\
\hline 6 & $\begin{array}{l}\text { Ketersediaan } \\
\text { marka dan } \\
\text { rambu-rambu } \\
\text { sepeda }\end{array}$ & $\begin{array}{l}\text { Adanya } \\
\text { pembangunan } \\
\text { marka dan rambu- } \\
\text { rambu khusus } \\
\text { sepeda yang sesuai } \\
\text { untuk } \\
\text { menghindari } \\
\text { kecelakaan lalu } \\
\text { lintas dan } \\
\text { meningkatkan } \\
\text { keselamatan } \\
\text { pengguna sepeda }\end{array}$ \\
\hline 7 & $\begin{array}{l}\text { Memberikan } \\
\text { pendidikan } \\
\text { mengenai } \\
\text { keselamatan } \\
\text { berkendara } \\
\text { sepeda }\end{array}$ & $\begin{array}{l}\text { Adanya kelas atau } \\
\text { materi khusus } \\
\text { mengenai } \\
\text { keselamatan } \\
\text { berkendara } \\
\text { menggunakan } \\
\text { sepeda yang } \\
\text { diajarkan oleh } \\
\text { guru atau trainer } \\
\text { dari pihak Dinas } \\
\text { Perhubungan agar } \\
\text { para pelajar dapat } \\
\text { mengerti } \\
\text { mengenai } \\
\text { keselamatan } \\
\text { berkendara ketika } \\
\text { menggunakan } \\
\text { sepeda seperti } \\
\text { rambu-rambu } \\
\text { khusus sepeda, } \\
\text { berkendara ketika } \\
\text { malam hari, } \\
\text { perlengkapan }\end{array}$ \\
\hline
\end{tabular}




\begin{tabular}{|l|l|l|}
\hline No & Strategi & \multicolumn{1}{|c|}{$\begin{array}{c}\text { Program } \\
\text { Pendukung }\end{array}$} \\
\hline & & $\begin{array}{l}\text { keselamatan yang } \\
\text { diperlukan dan } \\
\text { lain sebagainya. }\end{array}$ \\
\hline
\end{tabular}

\section{Rekomendasi}

Adapun beberapa sekolah dengan pelajar yang telah menggunakan sepeda ke sekolah seperti:

a. SMP : 13, 48, 39, 43, 24, 38, 20, 30, dan

BPK Penabur

b. SMA : 4, 21, 8, 11, dan 22

SMK : 4, 5, 6, 8, dan 14

Dengan jumlah keseluruhan pelajar di Kota Bandung mencapai 397.555 pelajar dari tingkat SD, SMP, SMA, dan SMK baik negeri maupun swasta. Sehingga jumlah pelajar ini merupakan jumlah potensi siswa pengguna sepeda dengan asumsi kepemilikan sepeda di Kota Bandung mencapai 993.788 unit, sangat memungkinkan untuk mewujudkan program Bike to School di Kota Bandung. Selain itu apabila dilihat dari peraturan mengenai jarak maksimal rayonisasi yakni $2 \mathrm{~km}$ dari rumah maka sangat memungkinkan bagi para siswa untuk menggunakan sepeda karena berdasarkan penelitian, penggunaan sepeda bisa mencapai $5 \mathrm{~km}$. Selain itu dengan memperhatikan topografi jalan-jalan di Kota Bandung yang memiliki tanjakan, para siswa dapat menggunakan sepeda elektrik untuk memudahkan siswa dalam melakukan perjalanan dari rumah ke sekolah.

Sehingga apabila program bike to school wajib dilakukan maka tidak ada alasan bagi para siswa untuk menolak menggunakan sepeda ke sekolah.

Diperlukan dukungan dari semua pihak terkait penggunaan sepeda ke sekolah, baik dari segi infrastruktur seperti ketersediaan jalur sepeda yang terintegrasi hingga tempat parkir sepeda yang memadai. Namun hingga saat ini masih sulit untuk mewujudkan jalur khusus sepeda yang sesuai fungsinya karena kurangnya kesadaran para pengguna jalan. Maka dari itu perlu adanya kajian lebih lanjut mengenai kesediaan masyarakat pengguna sepeda untuk berbagi jalan dengan pengguna kendaraan bermotor atau menginginkan jalur tersendiri khusus pengguna sepeda

\section{Daftar Pustaka}

Dwi Sulistyo, dkk, "Upaya Penggunaan Sepeda Sebagai Moda Transportasi di Kota Surabaya", diakses dari http://repository.gunadarma.ac.id/186/1/ Upaya\%20Penggunaan \%20Sepeda $\% 20$ Sebagai\%20Moda\%20Transportasi\%20 Di\%20Kota\%20Surabaya_UG.pdf, pada tanggal 25 Desember 2016

Ferry Himawan, "Masalah Transportasi dan Solusi dengan Transportasi Berkelanjutan", diakses dari http://ferryhimawan.blogspot.co.id/2010 /11/masalah-transportasi-dan-solusidengan_4330.html, pada tanggal 25 Desember 2016

Masterplan Jalur Sepeda Tahun 2015

Peraturan Daerah Kota Bandung Nomor 16 Tahun 2012 Tentang Penyelenggaraan Perhubungan dan Retribusi Di Bidang Perhubungan

Peraturan Pemerintah Nomor 26 Tahun 2008 diperlukan Rencana Tata Ruang Wilayah Provinsi (RTRWP) Jawa Barat

Rencana Tata Ruang Wilayah Kota Bandung

Surat Edaran Walikota Bandung Nomor 551/Se.079-Dishub Tentang Pengadaan Shelter Parkir Sepeda Di Kota Bandung Undang-Undang Nomor 22 Tahun 2009 Tentang Lalu Lintas dan Angkutan Jalan Undang-Undang Nomor 26 Tahun 2007 Tentang Penataan Ruang 